\title{
IN VIVO ASSESSMENT OF THE EFFECTS OF METHOTREXATE ON LATENT TOXOPLASMOSIS
}

By

\author{
SAMIA E. ETEWA ${ }^{1}$, DALIA A. ABO EL-MAATY ${ }^{1}$, MAI E. ABD EL-AZEEM ${ }^{1}$, \\ MAHMOUD A. EL-SHAFEY ${ }^{2}$, MOHAMED H. SARHAN ${ }^{*}$, EMAN H. ABDEL BARY ${ }^{3}$ \\ AND EMAN SAAD ${ }^{1}$ \\ Departments of Medical Parasitology ${ }^{1}$, Clinical Pathology ${ }^{2}$ and Pathology ${ }^{3}$, Faculty of \\ Medicine, Zagazig University, Egypt ( ${ }^{\star}$ Correspondence: drsarhan@gmail.com) \\ Abstract
}

Toxoplasma gondii (T. gondii) has been shown to result in life-threatening encephalitis in immunocompromised patients after reactivation of dormant parasites. The present work aimed to assess the effects of methotrexate on reactivation of latent toxoplasmosis alone and combined with a therapeutic combination of spiramycin, pyrimethamine and folinic acid on the progress of the disease. Forty-four laboratory-bred Swiss albino male mice were infected with Me49 nonvirulent strain of $T$. gondii and equally divided into four groups: infected untreated control (I); infected and treated with combination of spiramycin, pyrimethamine and folinic acid (II); Infected and received methotrexate (III); and infected and received both methotrexate, spiramycin, pyrimethamine and folinic acid (IV). The mean number and size of tissue cysts in brain smears of mice of each group were determined, serum levels of anti-Toxoplasma IgM were assessed in different study groups by an enzyme linked immunosorbent assay and histopathological examination of brain and liver were done. The results showed that the mean serum IgM level was significantly different in the treated groups compared to that in infected control group. The highest level of serum IgM was found in the infected and received methotrexate group. After treatment with spiramycin, pyrimethamine and folinic acid, it was significantly decreased. In this study, reactivation of latent toxoplasmosis was observed by a significant increase in the mean number and sizes of Toxoplasma tissue cysts in brains of mice with established chronic toxoplasmosis after treatment with methotrexate alone or combined with spiramycin, pyrimethamine compared to both untreated chronically infected controls and infected mice treated with spiramycin, pyrimethamine and folinic acid. Moreover, considerable pathological lesions in the brain and liver was observed in groups received methotrexate alone or combined with spiramycin, pyrimethamine compared to both untreated chronically infected controls and infected mice treated with spiramycin, pyrimethamine and folinic acid.

Keywords: Toxoplasma gondii, Methotrexate, Spiramycin, Pyrimethamine, IgM, Histopathology.

\section{Introduction}

Toxoplasmosis is an opportunistic disease affects humans and warm-blooded animals caused by Toxoplasma gondii (Halonen and Weiss, 2013). Transmission to humans occurs either through ingestion of $T$. gondii oocysts shed by cats into the environment, eating the undercoooked meat of infected animals, blood transfusion, congenitally across the placenta and organ transplantation (Yazar et al, 2006). After the acute stage, the parasite forms cysts in variety of organs, including the brain, heart, and skeletal muscle, thereby establishing a chronic infection (El-Sayed et al, 2012). Antibodies play a minor role but remain the

essential means for diagnosing toxoplasmosis in humans (Stray-Pedersen, 1997). The antibodies act on the extracellular tachyzoites released following lysis of infected cells (Xu et al, 2005).

Toxoplasma $\operatorname{IgM}$ is the first antibody to appear in infected patients, detected at the surface of the parasite, from the second day following infection. However, it can be persistent and depending on the tests used, it can be detected for shorter or longer periods of time making the interpretation of serological results sometimes difficult (Roberts et 
al., 2001). These immunoglobulins are the best activators of the complement system. In addition, due to its structure, it enables excellent agglutination and has a high level of cytotoxicity. This phenomenon is used especially in serological diagnostic techniques (Huang et al, 2012).

T. gondii infection in immunocompetent individuals is mostly asymptomatic or can be manifested as lymphadenopathy and is usually followed by a lifelong latent infection that may be reactivated as a result of immune disorders inducing serious complications (Meers, 2010). This reactivation of latent infection may occur due to acquired immunodeficiency syndrome (AIDS), organ transplantation, hematopoietic stem cell transplantation, or cancer chemo-therapy as methotrexate (MTx) (Halonen and Weiss, 2013). Cerebral toxoplasmosis in patien-ts receiving multiple immunosuppressive medications, including methotrexate, cortisone infliximab and leflunomide for rheumatoid arthritis has been reported (Young and McGwire, 2005).

Methotrexate (MTx) is an antimetabolite chemotherapeutic agent that binds to the enzyme dihydrofolate reductase, which is involved in the synthesis of purine nucleotides. This interferes with DNA synthesis and disrupts cell multiplication (Wessels et $a l, 2008)$.

MTx appears to have multiple sites of action within the immune system. They include stimulation of interleukin-2 production, antiproliferative effects on $\mathrm{B}$ and $\mathrm{T}$ cells (Quéméneur et al, 2003), inhibition of histamine release from basophils, and inhibition of immunoglobulin production (Montesinos et al, 2003; Bunescu et al, 2004). Reactivation of latent murine $T$. gondii was induced by long administration of immunosuppressive drugs as dexamethasone (DXM) and associated with increased brain cysts burden and marked decrease in spleen size and cellularity (Sumyuen et al, 1996).

Treatment of toxoplasmosis patients includes a variety of therapeutic protocols which comprises sulphadiazine and pyrimethamine with vitamin supplements continued for 6 weeks (Holliman, 2009). A potent antitoxoplasmosis like spiramycin, a macrolide antibiotic produces high tissue concentration, especially in the placenta, but does not cross the placental barrier, and has been given to pregnant women who were primarily infected with Toxoplasma during this pregnancy without teratogenic effects to the fetus as it is relatively nontoxic to the mother and the fetus (Vaz et al., 2011).

The aim of this study was to assess in vivo the effects of methotrexate in reactivation of latent toxoplasmosis alone and with a therapeutic combination of spiramycin, pyrimethamine and folinic acid on the progress of the disease.

\section{Materials and Methods}

An experimental study was conducted at Medical Parasitology Department (PostGraduate Research Laboratory), Faculty of Medicine, Zagazig University, Sharkia Governorate, Egypt.

Brain cysts of the Me49 non-virulent strain of $T$. gondii were kindly provided by Department of Medical Parasitology, Faculty of Medicine, Alex, Egypt. The parasite strain was regularly maintained by repeated inoculation of Swiss albino mice every 8 weeks with $0.1 \mathrm{ml}$ of brain homogenate of previously infected mice containing, approximately, $1 \times 10^{2}$ cysts $/ \mathrm{ml}$ to establish chronic toxoplasmosis (El-Sayed and Aly, 2014).

Experimental design: Laboratory-bred male Swiss albino mice, 10 weeks-old, each weighing 20-25 g were selected from the animal house of Faculty of Medicine, Zagazig University. They were housed in plastic cages with white wood chips for bedding, fed by commercial complete food mixture and tap water for drinking, and maintained under controlled conditions of lighting ( $12 \mathrm{~h}$ light/12 h dark cycle) and temperature (25 \pm $2 \mathrm{oC}$ ). Mice were inoculated intraperitoneally with $0.1 \mathrm{ml}$ of the brain cysts suspension, which containing $1 \times 102$ cysts $/ \mathrm{ml}$. Four weeks after the infection, the efficiency of 
the experimental Toxoplasma infection in mice was confirmed by the complement fixation test for detection of specific antiToxoplasma-IgM (Ondriska et al, 2003) and mice with undetected or very low concentrations of specific antibodies were excluded from the experiment. The final set of experimental animals included 44 mice. Animals were divided into four groups of 11 mice each: Group I (GI) infected untreated control group, Group II (GII) infected and treated with combination of spiramycin at a dose of $100 \mathrm{mg} / \mathrm{kg} /$ day (Filice and Pomeroy, 1991), pyrimethamine at a dose of $12.5 \mathrm{mg} / \mathrm{kg} /$ day and folinic acid at a dose of 10-25 mg orally daily (Romand et al, 1993). The drugs were provided in powder form and prepared daily as liquid suspensions; after brief sonication, the homogenized suspensions were administered orally to mice via tube feeding. Six weeks post-infection; treatments were administered daily at a fixed hour for 10 days, Group III (GIII) Infected and received methotrexate (MTX). Four weeks postinfection; infected mice were injected intraperitonially by MTX at a dose of $5 \mathrm{mg} / \mathrm{kg}$ every 48 hours for 3 doses, Group IV (GIV)T. gondii infected mice and received both MTX as GIII and combined treatment as GII. At the end of the experiment (6 weeks post the last dose of the administered drugs), the blood was collected from the mouse's orbital sinus (Hoff and Rlagt, 2000). The sera were separated and stored at $-20^{\circ} \mathrm{C}$ until the determination of anti-Toxoplasma antibody (IgM) serum levels. Then all mice were sacrificed by cervical dislocation. The effect of the used drugs was evaluated by:

Immunological study: Determination of anti-Toxoplasma IgM in sera samples using commercially available ELISA kit (Catalogue No. 201-11-1845 Egypt). The kit uses a double-antigen sandwich enzyme-linked immunosorbent assay (ELISA). Serum samples are added to enzyme well which is precoated with mice anti-Toxoplasma IgM antibody (anti-toxIgM) antigen, then incubation.
Anti-Toxoplasma IgM antibody (anti-tox IgM) antigen is added labeled with biotin, and combined with Streptavidin-HRP to form immune complex; then incubation and washing are carried again to remove the enzyme-linked immunosorbent assay uncombined enzyme. Chromogen Solution A, B was added; the color of the liquid changes into the blue, and at the effect of acid, the color finally becomes yellow. The chroma of color and the concentration of the mice antiToxoplasma IgM antibody (anti-tox IgM) of sample are positively correlated. The optical density (OD) was measured at $450 \mathrm{~nm}$. The sensitivity cut off was equal the average value of negative control well +0.15 .

Parasitological study: Counting the brain cysts number and measuring of their size. The brains of the sacrificed mice were grinded individually in a mortar. Then, $5 \mathrm{ml}$ of normal saline were added to the grinded brain tissue of each mouse obtaining brain emulsion homogenates. The total number of cysts per mouse brain was then estimated from four separate drops that were placed on glass slides and examined by bright-field microscope at 10 magnification (Djurkovic'Djakovic'et al, 2002). Then, the mean cysts number in each group was calculated.

After that, the slides were placed in room temperature to dry completely, and were then fixed using absolute methanol. Fix smears were stained with $20 \%$ Giemsa solution (Merck, Darmstadt, Germany) in pH 6.8 of phosphate buffer for $20 \mathrm{~min}$. Measuring brain cysts size of each group was done by computerized image analysis and accordingly the mean size in each group was calculated.

Histopathological study: Specimens from brain and liver were collected and fixed in $10 \%$ formadehyde solution for $24-48$ hours. The tissue was dehydrated in an ethyl alcohol series, cleared in xylene and embedded in paraffin and further histological processing were performed. Then microtomy was performed to obtain two histological slices for each tissue, $5 \mu$ thick, which were 
extended on clean slides, stained by hematoxylin and eosin (H\&E) and mounted with the aid of Canada balsam and coverslips (Abdel Wahab et al, 1989).

Ethical consideration: All procedures in the present study met the International Guiding Principles for Biomedical Research Involving Animals, as issued by the International Organizations of Medical Sciences (National Research Council, 2006) and approved by Ethics Committee of the Faculty of Medicine, Zagazig University.

Statistical analysis: Data were analyzed using the Statistical Package for Social Science (SPSS) for windows version 11.0 with student $(\mathrm{t})$ test and ANOVA test (analysis of variance) to evaluate the possible differences between the study groups. P values of less

Table 1: Comparison among mean values of ELISA(IgM) in studied groups using ANOVA test.

\begin{tabular}{|l|c|c|c|c|c|c|}
\hline ELISA & $\begin{array}{c}\text { GI: Infected } \\
\text { control }(\mathrm{N}=11)\end{array}$ & $\begin{array}{c}\text { GII: Spiramycin, Py- } \\
\text { rimethamine }(\mathrm{N}=11)\end{array}$ & $\begin{array}{c}\text { GIII:Methotrex- } \\
\text { ate }(\mathrm{N}=11)\end{array}$ & $\begin{array}{c}\text { GIV: Methotrexate, spiramycin, pyri- } \\
\text { methamine \& folinic acid }(\mathrm{N}=11)\end{array}$ & $\begin{array}{c}\mathrm{F} \\
\mathrm{P}\end{array}$ \\
\hline$M \pm S D$ & $0.32 \pm 0.06$ & $0.28 \pm 0.08$ & $0.40 \pm 0.05$ & $0.37 \pm 0.04$ & 8.82 & $<0.001 * * *$ \\
Range & $0.28-0.37$ & $0.23-0.36$ & $0.38-0.47$ & $0.35-0.41$ & \\
\hline
\end{tabular}

than $0.05,0.01$ or 0.001 were used to indicate statistical significance.

\section{Results}

There was highly significant increase in serum IgM level in groups treated with methotrexate alone (GIII) compared to GI (P $<0.01)$. Significant increase in serum $\operatorname{IgM}$ level in methotrexate, spiramycin, pyrimethamine and folinic acid GIV compared to GI $(\mathrm{P}<0.05)$.It was observed nonsignificant difference between methotrexate GIII \& methotrexate, spiramycin, pyrimethamine and folinic acid GIV $(\mathrm{P}>0.05)$. But, there was significant decrease in serum IgM level in spiramycin and pyrimethamine GII compared to GI $(\mathrm{P}<0.05)$.
Statistical analysis showed highly significant difference in tissue cysts size among some groups $(\mathrm{P}<0.001)$. There was highly significant increase in tissue cysts size in GIII compared toinfected GI $(\mathrm{P}<0.01)$. There was significant increase in tissue cyst size in methotrexate, spiramycin, pyrimethamine and folinic acid GIV compared

Table 2: Comparison among mean values of cyst size in studied groups using ANOVA test
\begin{tabular}{|c|c|c|c|c|c|c|}
\hline & GI & GII & GIII & GIV & F & P \\
\hline Size: $\mathrm{M} \pm$ SD & $28.4 \pm 3.67$ & $14.4 \pm 1.27$ & $41.29 \pm 5.51$ & $36.46 \pm 10.73$ & 39.79 & $<0.001 * * *$ \\
Range & $17.5-33$ & $13.3-17.5$ & $33-50$ & $23-60$ & & \\
\hline
\end{tabular}
SD: Standard Deviation. ***: very highly significant $(\mathrm{p}<0.001)$.

There was very high significant increase in number of tissue cysts in methotrexate GIII compared to GI $(\mathrm{P}<0.001)$. Significant increase in number of cysts was in methotrexate, spiramycin, pyrimethamine and folinic acid GIV compared to GI $(\mathrm{P} \backslash<0.05)$. Nonsignificant difference between methotrexate

Table 3: Comparison among mean values of cysts number in studied group using ANOVA test:

\begin{tabular}{|l|c|c|c|c|c|c|}
\hline item & GI & GII & GIII & GIV & F & P \\
\hline$M \pm S D$ & $635.45 \pm 144.86$ & $544.55 \pm 129.53$ & $904.09 \pm 175.66$ & $785 \pm 129.83$ & & $<0.00$ \\
Range & $480-810$ & $380-660$ & $800-1010$ & $640-930$ & 13.04 & $1 * * *$ \\
\hline
\end{tabular}

SD: Standard Deviation. ***: very highly significant $(\mathrm{p}<0.001)$.
Histopathology of brain sections stained by $\mathrm{H} \& \mathrm{E}$ showed moderate lymphocytic in-
GIII and methotrexate, spiramycin, pywas noticed. Also, there was significant decrease in number of cysts in spiramycin and pyrimethamine GII compared to GI (P < $0.05)$. rimethamine and folinic acid GIV $(\mathrm{P}>0.05)$

to infected GI $(\mathrm{P}<0.05)$. It was noticed nonrimethamine and folinic acid treated GIV $(\mathrm{P}>0.05)$. But, there was very high significant decrease in tissue cyst size in spiramycin and pyrimethamine treated group (GII) compared to infected GI $(\mathrm{P}<0.001)$.

filammatory infiltrate in GI (Fig. 8), mild infilammatory infiltrate in spiramycin and 
pyrimethamine GII (Fig. 9), but, diffuse lymphocytic infilammatory infiltrate in both methotrexate GIII (Fig. 10) and methotrexate, spiramycin and pyrimethamine GIV (Fig. 11). Histopathology of liver section stained by H\&E stain showed liver necrosis and infilammation in GI (Fig. 12). Spiramycin and pyrimethamine GII revealed reduction in extent and severity of the hepatic lobular and portal inflammatory response, with reduced inflammatory cell infiltrates (Fig. 13). Methotrexate GIII revealed with extensive liver fibrosis and lytic necrosis (Fig. 14). Methotrexate, spiramycin and pyrimethamine GIV revealed variable hepatocyte ballooning and hydropic degeneration (Fig. 15).

\section{Discussion}

Toxoplasmosis is an important opportunistic infection in immunocompromised patients (Munoz et al, 2011). It is an obligate intracellular replication parasite (Ferreira da Silva et al, 2008), releasing more tachyzoites, which may form cysts containing bradyzoites especially in the brain that evade the immune system and remain in tissues (Skariah et al, 2010). The cysts remain in the host tissues for years without causing any local inflammatory reaction which is controlled mainly by cellular immune mechanisms (Hunter et al, 1996). However, impairment of the balance between the host immune response and the parasite evasion of the immune response causes cyst rupture and renewed parasite proliferation and this may lead to clinical reactivation (Sullivan $e t$ al, 2009).

The advent of AIDS and use of intensive immunosuppressive drugs for the treatment of malignant and systemic diseases, or pre/post organ transplantation, have established a population of immunocompromised individuals prone to reactivation of opportunistic pathogens, including $T$. gondii, particularly in geographic areas with a high exposure to this protozoan (Bernsteen et al, 1999). So, reactivation of toxoplasmosis was considered a serious complication in patients given methotrexate (Pulivarthi et al, 2015).

Diagnosis of reactivated chronic toxoplasmosis is confirmed by detection of specific antibodies in serum as IgM antibody using ELISA technique which is more sensitive and specific than IgM-IFA and can detect IgM antibodies for a longer time (Pinon et al, 2001).

In the present study, there was significant increase in Toxoplasma IgM level in serum samples of infected mice treated with methotrexate alone or combined with spiramycin, pyrimethamine and folinic acid compared to control group. These results agree with Kuba et al. (2014) who found the seroprevalence of $T$. gondii IgM was highly significant increase in rheumatoid arthritis patients receiving methotrexate in comparison to patients without treatment (control group) and the presence of Toxoplasma IgM antibodies in $20.4 \%$ of $\mathrm{T}$. gondii $\mathrm{IgG}$ positive patients indicated the reactivation of $T$. gondii infection in them. In contrast, Kang et al. (2006) found that after dexamethasone treatment (immunosuppressive drug) of experimental mice infected with toxoplasma, serum IgM titer was depressed significantly. Moreover, the decrease in IgM level in group treated with spiramycin and pyrimethamine in our study may be attributed to the effective role of a combination of spiramycin and pyrimethamine in parasite killing and limiting the infection.

During the chronic stage of $T$. gondii infection, bradyzoites slowly multiply within the cysts and cyst sizes increase respectively (Dubey et al, 1998). In the present study, reactivation of latent toxoplasmosis was observed by highly significant increase in the mean size and number of Toxoplasma tissue cysts in brains of mice with chronic toxoplasmosis after treatment with methotrexate alone or combined with spiramycin, pyrimethamine and folinic acid compared to both chronically infected controls and infected mice treated with spiramycin, pyrimethamine and folinic acid. These results agree with El-Sayed et al., (2016) who 
found a significant increase in the mean number and sizes of Toxoplasma tissue cysts in brains of mice with established chronic toxoplasmosis after reactivation of latent toxoplasmosis by treatment with etanercept alone or combined with conventional treatment compared to both untreated chronically infected controls and infected mice treated with sulfadiazine and pyrimethamine. The present study found high significant decrease in the mean size and number of Toxoplasma cysts in brains of mice treated with spiramycin, pyrimethamine compared to chronically infected controls. This was due to the fact that pyrimethamine has a synergistic action by inhibiting $T$. gondii folic acid synthesis, essential for parasite survival and replication (Doliwa et al, 2013).

The histopathological examination of brain tissue of infected control mice showed prescence of infilammatory infiltrate reaction reflected mainly by proliferation of lymphocytes. In the present study, histopathological examination of brain tissue of mice treated with spiramycin, pyrimethamine and folinic acid showed mild infilammatory infiltrate reaction compared to methotrexate treated group and infected control group. The repair of the lesions by treatment leads to reduce the number of damaged cells. Prompt treatment may achieve rapid resolution, decrease inflammatory damage, prevent more tissue destruction and decrease the chances of the parasite dissemination. Those agree with Soheilian et al. (2011) who found that classic therapy (pyrimethamine, sulfadiazine) for Toxoplasma retinochoroiditis can reduce lesion size and vitreal inflammation as well as improve visual acuity.

In the present study, histopathological examination of brain tissue of mice treated with methotrexate showed massive increase in number of tissue cysts and prescence of diffuse lymphocytic infilammatory infiltrate reaction compared to infected control group and spiramycin, pyrimethamine treated group. These data agreed with Djurk-
ović-Djaković and Milenković (2001) who observed that high mortality of mice treated with dexamethasone (DXM) and cortisone acetate (CA) was associated with increased brain cyst burdens compared to both healthy and infected untreated mice and prescence of perivascular and meningeal infiltration consistent with the diagnosis of meningoencephalitis, despite the anti-inflammatory activity of corticoids due to reactivation of previously latent murine $T$. gondii infection.

In the present study, histopathological examination of liver tissue in infected control mice showed presence of liver infilammation and areas of necrosis. These findings are in agreement with Rifaat et al. (1981) who found that chronic infection of Toxoplasma gondii in liver of rat cause vascular congestion with localized areas of haemorraghe and liver cells around haemorraghic areas were necrosed and brown pigments were seen. Mady et al. (2016) found also that the hepatic lobules reveal moderate inflammatory cell infiltrate with frequent spotty necrosis as well as focal confluent necrosis. We found that treatment by methotrexate alone or combined with spiramycin, pyrimethamine and folinic acid causes extensive liver fibrosis, hepatocytes ballooning and hydropic degeneration. This finding approved the predominance of the immunosuppressive effect of methotrexate and its ability to reactivate Toxoplasma gondii. Marked reduction in the pathological changes observed in liver sections in spiramycin, pyrimethamine treated group as compared to infected control group. This revealed remarkable therapeutic effects of a combination of spiramycin and pyrimethamine against chronic toxoplasmosis.

\section{Conclusion}

The outcome data showed that methotrexate as an immunosuppressive drug have a role in reactivation of latent toxoplasmosis in murine models evidenced by increasing size and number of brain tissue cysts. Its immunosuppressive effect predominates the therapeutic effects of a potent antitoxoplas- 
mosis combination even if combined with it. Serological screening for cases offers a valuable aid for patients who must be treated with methotrexate.

\section{References}

Abdel Wahab, RM, Morsy, TA, Bahgat, A B, Abdel Rahim, MI, Essa, MH, et al, 1989: The histopathological picture of concomitant infection with Leishmania major and Toxoplasma gondii in albino mice. J. Egypt. Soc. Parasitol. 19, 1:1-12.

Bernsteen, L, Gregory, CR, Aronson, LR, Lirtzman, RA, Brummer, DG, 1999: Acute toxoplasmosis following renal transplantation in three cats and a dog. J. Am. Vet. Med. Ass. 215: 1123-6.

Bunescu, A, Seideman, P, Lenkei, R, Levin, K, Egberg, N, 2004: Enhanced Fc gamma receptor I, alpha-M beta2 integrin receptor expression by monocytes and neutrophils in rheumatoid arthritis: interaction with platelets. J. Rheumatol. 31:2347-55.

Djurković-Djaković, O, Milenković, V, 2001: Murine Model of drug-induced reactivation of Toxoplasma gondii. Acta Protozool. 40:99-106.

Djurković-Djaković, O, Milenković, V, Nikolić, A, Bobić, B, Grujić, J, 2002: Efficacy of atovaquone combined with clindamycin against murine infection with a cystogenic (Me49) strain of Toxoplasma gondii. J. Antimicrob. Chemother. 50, 6:981-7.

Doliwa, C, Xia, D, Escotte-Binet, S, Newsham, EL, Sanderson, SJ, et al, 2013: Identification of differentially expressed proteins in sulfadiazine resistant and sensitive strains of Toxoplasma gondii using difference-gel electrophoresis (DIGE). Int. J. Parasitol. Drugs Drug Resist. 3:35-44.

Dubey, JP, Lindsay, DS, Speer, CA, 1998: Structure of Toxoplasma gondii tachyzoites, bradyzoites, and sporozoites and biology and development of tissue cysts. Clin. Microbiol. Rev. 11:267-99.

El-Sayed, NM, Aly, EM, 2014: Toxoplasma gondii infection can induce retinal DNA damage: an experimental study. Int. J. Ophthalmol. 7, 3:431-6.

El-Sayed, NM, Ismail, KA, Ahmed, SA, EzzEl-Din, HM, Azzam, HM, 2012: Possible association between Toxoplasma gondii infection and schizophrenia: Egyptian study. Infect. Dis. Clin. Pract. 20, 6:394-9.
El-Sayed, NM, Ismail, KA, Badawy, AF, Elhasanein, KF, 2016: In vivo effect of anti-TNF agent (etanercept) in reactivation of latent toxoplasmosis. J. Parasit. Dis. 40, 4:1459-65.

Ferreira da Silva, MF, Barbosa, HS, Gross, U, Luder, CG, 2008: Stress related and spontaneous stage differentiation of Toxoplasma gondii. Mol. Biosyst. 8:824-34.

Filice, GA, Pomeroy, C, 1991: Effect of clindamycin on pneumonia from reactivation of Toxoplasma gondii infection in mice. Antimicrob. Agents Chemother. 35:780-2.

Halonen, SK, Weiss, LM, 2013: Toxoplasmosis. Hndb. Clin. Neurol. 114:125-45.

Hoff, J, Rlagt, LV, 2000: Methods of blood collection in the mouse. Lab Anim. 29, 10:4753. Holliman, RE, 2009: Toxoplasmosis. In: Cook, GC. and Zumla AI. (eds) Manson's Tropical diseases, $22^{\text {nd }}$ ed., Chapter 78. Saunders.

Huang, X, Li, J, Zhang, G, Gong, P, Yang, J, et al, 2012: Toxoplasma gondii: Protective immunity against toxoplasmosis with recombinant actin depolymerizing factor protein in BALB/c mice. Exp. Parasitol. 130, 3:218-22.

Hunter, CA, Suzuki, Y, Subauste, CS, Remington, JS, 1996: Cells and cytokines in resistance to Toxoplasma gondii. Curr. Trop. Microbiol. Immunol. 219:113-25.

Kang, KM, Choi, IU, Shin, DW, Lee, YH, 2006: Cytokine and antibody responses of reactivated murine toxoplasmosis upon administrat ion of dexamethasone. Korean J. Parasitol. 44, 3: 209-19.

Kuba, RH, Zghair, KH, Alosami, MH, 2014: Detection of Toxoplasma antibodies and TNF$\alpha$ in rheumatoid arthritis patients treated with methotrexate. Iraqi J. Sci. 55:1535-40.

Mady, RF, El-Hadidy, W, Elachy, S, 2016: Effect of Nigella sativa oil on experimental toxoplasmosis. Parasitol Res. 115:379-90.

Meers, S, Lagrou, K, Theunissen, K, et al, 2010: Myeloablative conditioning predisposes patients for Toxoplasma gondii reactivation after allogeneic stem cell transplantation, Clin. Infect. Dis. 50, 8:1127-34.

Montesinos, MC, Desai, A, Delano, D, Chen, JF, Fink, JS, et al, 2003: Adenosine A2A or A3 receptors are required for inhibition of inflammation by methotrexate and its analog MX-68. Arthritis Rheum. 48, 1:240-7.

Munoz, M, Liesenfeld, O, Heimesaat, MM, 2011: Immunology of Toxoplasma gondii. Immunol. Rev. 240:269 -85. 
National Research Council, 2006: Guidelines for the humane transportation of research animals. Washington, DC: National Academies Press. Ondriska, F, Catar, G, Vozarova, G, 2003: The significance of complement fixation test in clinical diagnosis of toxoplasmosis. Bratisl LekListy 104, 6:89-196.

Pinon, JM, Dumon, C, Chemla, J, Franck, E, Petersen, M, et al, 2001: Strategy for diagnosis of congenital toxoplasmosis: evaluation of methods comparing mothers and newborns and standard methods for postnatal detection of immunoglobulin G, M, and A antibodies. J. Clin. Microbiol. 39, 6:2267-71.

Pulivarthi, S, Reshi, RA, McGary, CT, Gurram, MK, 2015: Cerebral toxoplasmosis in a patient on methotrexate and infliximab for rheumatoid arthritis. Inter. Med. 54, 11:433-6.

Quéméneur, L, Gerland, LM, Flacher, M, French, M, Revillard, JP, et al, 2003: Differential control of cell cycle, proliferation, and survival of primary $\mathrm{T}$ lymphocytes by purine and pyrimidine nucleotides. J. Immunol. 170:4986-95.

Rifaat, MA, Salem, SA, Azab, ME, Beshira, SR, Safer, EH, et al, 1981: Effect of Toxoplasma gondii on histopathology and histochemistry of reticuloendothelial system in experimental animals. Folia Parasitol. (Praha), 28:117-24.

Roberts, A, Hedman, K, Luyasu, V, 2001: Multicenter evaluation of strategies for serodiagnosis of primary infection with Toxoplasma gondii. Eur. J. Clin. Microbiol. Infect. Dis. 20: 467-74.

Romand, S, Pudney, M, Derouin, F, 1993: In vitro and in vivo activities of the hydroxynaphthoquinone atovaquone alone or combined with pyrimethamine, sulfadiazine, clarithromycin, or minocycline against Toxoplasma gondii. Antimicrob. Agents Chemother. 37, 11:2371-8.

Skariah, S, McIntyre, MK, Mordue, DG, 2010: Toxoplasma gondii: determinants of tach zoite to bradyzoite conversion. Parasitol. Res. 107:253-60.

Soheilian, M, Ramezani, A, Azimzadeh, A, Sadoughi, MM, Dehghan, MH, et al, 2011: Randomized trial of intravitreal clindamycin and dexamethasone versus pyrimethamine, sulfadiazine, and prednisolone in treatment of ocular toxoplasmosis. Ophthal. 118, 1:134-41.

Stray-Pedersen, B, 1997: Uterine Toxoplasma infections and repeated abortions. Am. J. Obstet. Gynecol. 128:716-21.

Sullivan, WJ, Jr, Smith, AT, Joyce, BR, 2009: Understanding mechanisms and the role of differentiation in pathogenesis of Toxoplasma gondii -a review. Mem. Inst. Oswaldo Cruz 104, 2:155-61.

Sumyuen, MH, Garin, YJF, Dérouin, F, 1996: Effect of immunosuppressive drug regimens on acute and chronic murine toxoplasmosis. Parasitol. Res. 82:681-6.

Vaz, R, Thomaz, S, Sumikawa, E, Guimaraes, A, 2011: Serological prevalence of Toxoplasma gondii antibodies in pregnant women from Southern Brazil. Parasitol. Res., 106:661-5.

Wessels, JA, Huizinga, TW, Guchelaar, HJ, 2008: Recent insights in the pharmacological actions of methotrexate in the treatment of rheumatoid arthritis. Rheumatology (Oxford), 47, 3: 249-55.

Xu, LQ, Chen, YD, Sun, FH, Cai, L, Fang, YY, et al, 2005: A national survey on current status of the important parasitic diseases and control strategies. Chin. J. Parasitol. Dis. 23: 332-40.

Yazar, S, Eser, B, Yay, M, 2006: Prevalence of anti-Toxoplasma gondii antibodies in Turkish blood donors. Ethiop. Med. J. 44, 33:257-61.

Young, JD, Mc Gwire, BS, 2005: Infliximab and reactivation of cerebral toxoplasmosis. N. Engl. J. Med. 352:1530-1.

\section{Explanation of figures}

Fig. 1: Comparison among mean values of ELISA (IgM) in different groups.

Fig. 2: Comparison among mean values of cyst size in different groups.

Fig. 3: Comparison among mean values of cysts number in different groups.

Fig. 4: Tissue cysts (arrows) in brain tissue in GI (Giemsa stain) x100.

Fig. 5: Tissue cysts (arrows) in brain tissue of spiramycin and pyrimethamine GII (Giemsa Stain) x100.

Fig. 6: Tissue cysts (arrows) in brain tissue of methotrexate GIII (Giemsa Stain) x100.

Fig. 7: Tissue cysts (arrows) in brain tissue of methotrexate \& spiramycin and pyrimethamine GIV (Giemsa Stain) x100.

Fig. 8: Moderate lymphocytic infilammatory infiltrate (arrows) in brain section of GI (H\&E stain) x400.

Fig. 9: Mild infilammatory infiltrate (arrows) in brain section of spiramycin and pyrimethamine GII (H\&E stain) x400.

Fig. 10: Diffuse lymphocytic infiltration (arrows) in brain section of methotrexate GIII (H\&E stain) x400.

Fig. 11: Diffuse lymphocytic infilammatory infiltrate (arrows) in brain section of methotrexate \& Spiramycin and pyrimethamine GIV (H\&E stain) $\mathrm{x} 400$.

Fig. 12: Liver necrosis and infilammation in liver section of GI (H\&E stain) x400.

Fig. 13: Mild infilammatory cell infiltrate in liver section of spiramycin and pyrimethamine GII (H\&E stain) x400. 
Fig. 14: Extensive liver fibrosis and lytic necrosis in liver section of methotrexate GIII (H\&E stain) x400.

Fig. 15: Variable hepatocytes ballooning (arrows) and hydropic degeneration in liver section of methotrexate \& spiramycin and pyrimethamine GIV (H\&E stain) x400.
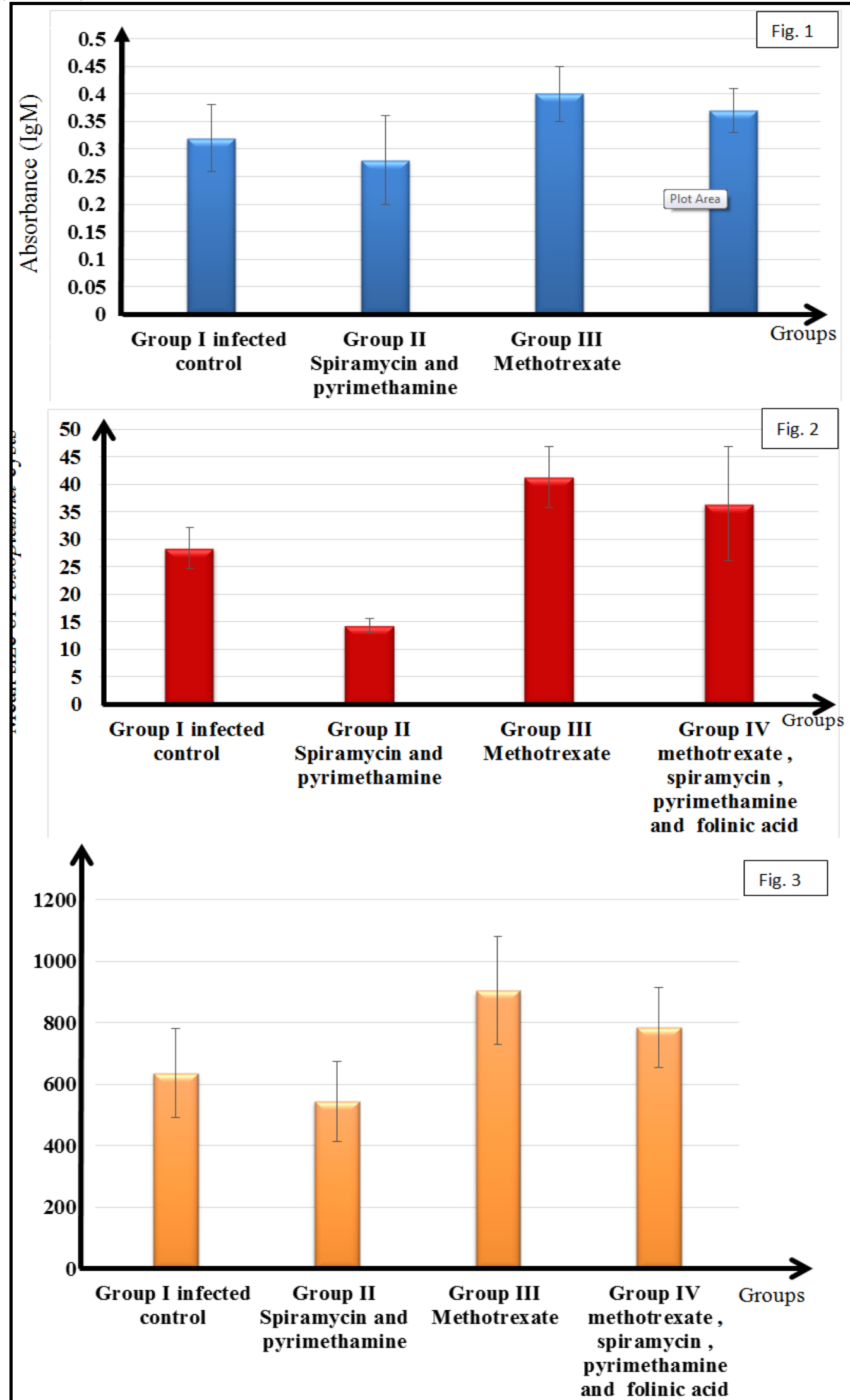


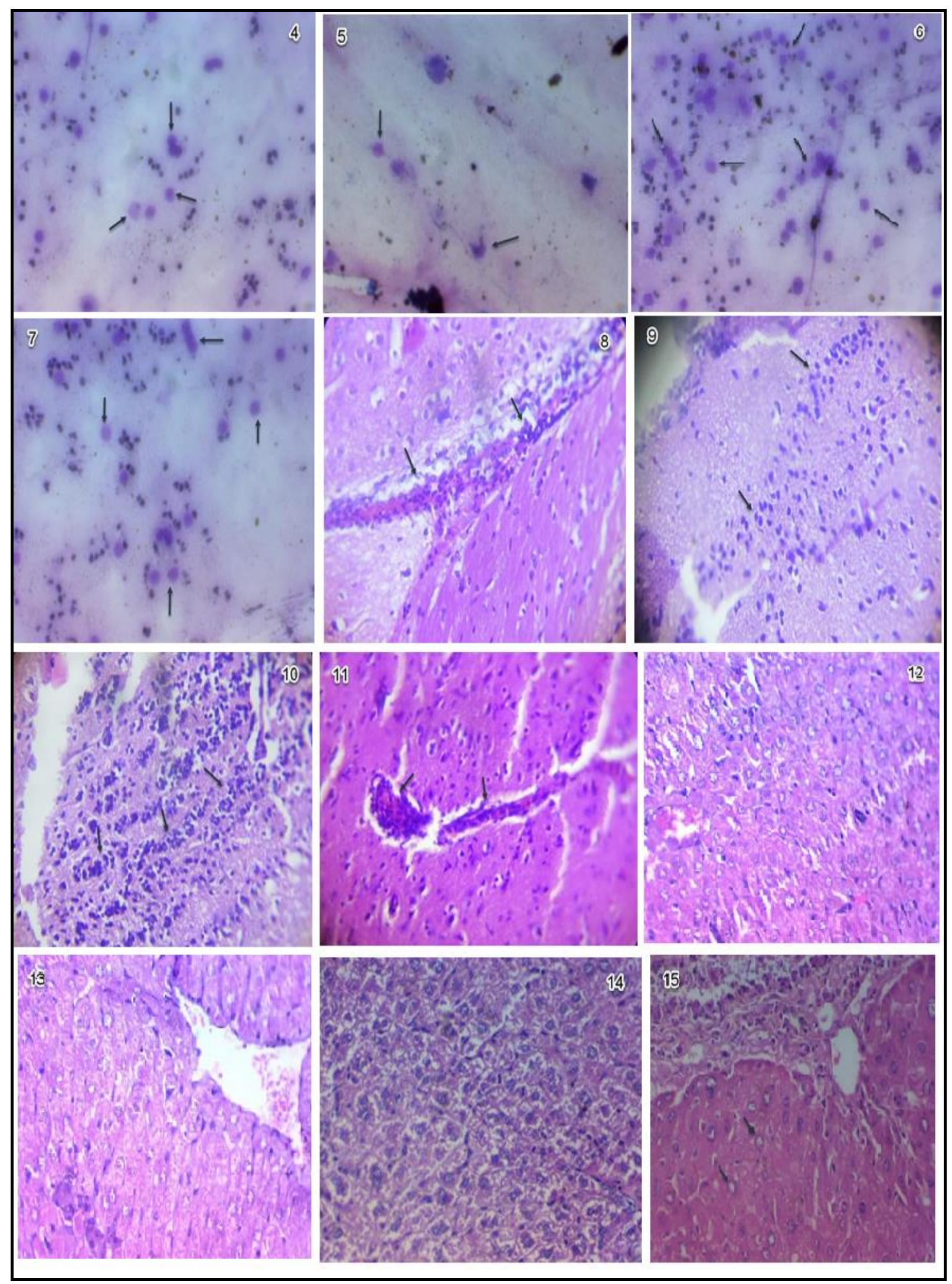

